[Chem. Pharm. Bull.]

[35(12)4953-4959(1987) $]$

\title{
Isolation and Characterization of Protease Modified Ribonucleases from Rhizopus sp.
}

\author{
Sachiko Mine, ${ }^{a}$ Eiji Wakabayashi, ${ }^{a}$ Akihiro Sanda, ${ }^{b}$ \\ Yoshio TaKizaWA, ${ }^{b}$ KAZUKO OHGI $^{a}$ \\ and MASACHIKA IRIE*,a \\ Department of Microbiology, Hoshi College of Pharmacy, ${ }^{a}$ Ebara 2-4-41, Shinagawa-ku, \\ Tokyo 142 and Faculty of Public Health, Azabu University, ${ }^{b}$ \\ Fuchinobe, Sagamihara, Kanagawa 229, Japan
}

(Received June 22, 1987)

\begin{abstract}
In order to clarify the reason for the variation in specific activities of ribonuclease preparations from Rhizopus sp. ribonuclease (RNase $\mathrm{Rh}$ ), low specific activity species ( $\mathrm{RNase} \mathrm{Rh}^{\prime}$ ) were separated from native RNase Rh by DEAE Toyopearl 650 column chromatography and characterized. When $\mathrm{RNase}^{\mathrm{Rh}} \mathrm{h}^{\prime}$ was subjected to gel electrophoresis in the absence of 2 mercaptoethanol, it gave a 24 kilodalton $(\mathrm{kDa})$ protein band, but in the presence of the reducing agent it gave 17 and $7 \mathrm{kDa}$ bands. These two peptides were separated by gel filtration and their $\mathrm{NH}_{2}$-terminal amino acid sequences were determined. The results indicated that $\mathrm{RNase}^{\mathrm{Rh}} \mathrm{h}^{\prime}$ was an enzyme species cleaved at about the 50th residue of native $\mathrm{RNase} R \mathrm{R}$ by proteases during the course of purification, but the two fragments were still covalently joined by S-S bridges. RNase $\mathbf{R h}^{\prime}$ retained about $70 \%$ of the native activity and has a similar conformation to the native enzyme.
\end{abstract}

Keywords_-Rhizopus; ribonuclease; proteolytic modification; $\mathrm{NH}_{2}$-terminal sequence

A base-nonspecific and adenylic acid-preferential ribonuclease (RNase $\mathrm{Rh}$ ) has been purified by Tomoyeda et al. ${ }^{1)}$ and Komiyama and Irie $^{2)}$ from Rhizopus sp. During the course of purification, we very often observed the presence of crystalline RNase $\mathrm{Rh}$ species having relatively low specific activity, about $70 \%$ of the highest one $(327 \mathrm{unit} / \mathrm{mg}$ protein) (RNase $\mathrm{Rh}^{\prime}$ ). In this paper, we report that the $\mathrm{RNase} \mathrm{Rh}$ preparation contained enzyme species modified by proteases at around the 50th residue from the N-terminal end of RNase Rh.

\section{Materials and Methods}

Reagents - Ribonucleic acid (RNA) used as a substrate was obtained from Kojin Co. Diethylaminoethyl (DEAE)-Toyopearl 650M was purchased from Toyo Soda (Tokyo). Marker proteins, ovalbumin, $\alpha$-chymotrypsinogen, cytochrome $\mathrm{c}$ and insulin, were purchased from Sigma Chem. Co.

Enzyme Preparation - RNase Rh preparations from Rhizopus sp. were purified according to the method reported previously, ${ }^{2)}$ and further subjected to column chromatography on DEAE-Toyopearl $650 \mathrm{M}$ at $\mathrm{pH} 7.5$.

Enzyme Assay - The standard assay used during purification was performed according to the previous paper ${ }^{2}$ using RNA as a substrate. Enzyme solution $(5-10 \mu \mathrm{l})$ was added to $2 \mathrm{ml}$ of reaction mixture consisting of $50 \mathrm{~mm}$ acetate buffer $(\mathrm{pH} 6.0)$ and $0.25 \%$ RNA, and the reaction was performed at $37^{\circ} \mathrm{C}$ for $1-5 \mathrm{~min}$, then terminated by adding $1 \mathrm{ml}$ of MacFadyen reagent. ${ }^{3}$ ) An aliquot $(0.3 \mathrm{ml})$ was diluted with $2 \mathrm{ml}$ of deionized water, and the absorbancy at $260 \mathrm{~nm}$ was measured. The amount of RNase which produced an increase in absorbancy of 1.0 at $260 \mathrm{~nm}$ after a $5 \mathrm{~min}$ incubation was defined as one unit.

Protein Concentration-Protein concentration was estimated by measuring the absorbancy at $280 \mathrm{~nm}$, taking that of a $0.1 \%$ solution as 1.0 .

Polyacrylamide Gel Electrophoresis - Disc electrophoresis on polyacrylamide gel was performed by the method of Ornstein ${ }^{4)}$ and Davis ${ }^{5}$ using $\mathrm{pH} 8.5$ gel. Gel electrophoresis was performed at the current of $2.5 \mathrm{~mA}$ per tube for $1.5 \mathrm{~h}$. Polyacrylamide gel electrophoresis in the presence of $0.1 \%$ sodium dodecyl sulfate (SDS) was performed according to the method of Shapiro et al. $\left.{ }^{6}\right)$ using $7 \%$ polyacrylamide gel. Electrophoresis was carried out 
for $4 \mathrm{~h}$ at $7 \mathrm{~mA}$ per tube. For both electrophoreses, approximately $20 \mu \mathrm{g}$ of protein was applied per tube. The gels were stained with $0.025 \%$ Coomassie brilliant blue. Slab-gel electrophoresis was conducted using $12 \%$ polyacrylamide gel according to the method of Laemmli.?

Molecular Weight Determination — The molecular weights of RNase Rh', and the peptides were estimated by gel filtration on Sephadex G-50 column $(1.5 \times 170 \mathrm{~cm})$ equilibrated with $50 \mathrm{~mm}$ trimethylamine-acetate buffer $(\mathrm{pH} 8.0)$ containing $0.1 \mathrm{M} \mathrm{NaCl}$ according to Andrews. ${ }^{8)}$ Fractions of $1.3 \mathrm{ml}$ each were collected. Marker proteins used were ovalbumin (MW 45000), $\alpha$-chymotrypsinogen (MW 25700), cytochrome c (MW 12400) and insulin (MW 6000).

Amino Acid Analysis Proteins and peptides were hydrolyzed in evacuated, sealed tubes with $6 \mathrm{~N} \mathrm{HCl}$ at $110^{\circ} \mathrm{C}$ for $24 \mathrm{~h}$. Analyses were performed by the method of Spackman et al.$^{9)}$ with an amino acid analyzer (Nihon Denshi JLC-200A). Estimation of tryptophan content was performed by the method of Pajot. ${ }^{10)}$

Automated Edman Degradation — A protein sample (about $0.3 \mu \mathrm{mol}$ ) was reduced and carboxymethylated in the presence of $8 \mathrm{M}$ urea according to the method of Crestfield et al. ${ }^{11)}$ The reduced and carboxymethylated protein and peptides were subjected to automated Edman degradation ${ }^{12)}$ with a JEOL JAS $47 \mathrm{~K}$ sequencer. Phenylthiohydrantoin (PTH)-amino acids were determined by high performance liquid chromatography (HPLC). HPLC was performed with JASCO Fine Sil $\mathrm{C}_{18-5}$ column $(4.6 \times 12.5 \mathrm{~cm})$ equilibrated with solvent $\mathrm{A}\left(0.05 \% \mathrm{H}_{3} \mathrm{PO}_{4}\right.$ : acetonitrile $=90: 10, \mathrm{v} / \mathrm{v})$. PTH-amino acids were eluted with a concave gradient of solvent $\mathrm{A}$ and solvent $\mathrm{B}(0.1 \%$ $\mathrm{H}_{3} \mathrm{PO}_{4}$ : acetonitrile $=60: 40, \mathrm{v} / \mathrm{v}$ ) for $16 \mathrm{~min}$ at a flow rate of $2.0 \mathrm{ml} / \mathrm{min}$, followed by elution with solvent $\mathrm{B}$. An aliquot of the PTH-amino acid was subjected to isocratic elution on a column of Zorbax ODS $(4.6 \times 25 \mathrm{~cm})$ with $12.5 \mathrm{~mm}$ acetate buffer $(\mathrm{pH} 4.5)$ containing $33 \%$ acetonitrile. PTH-amino acids were detected by measuring the absorbance at 254 or $315 \mathrm{~nm}$ (for dehydrothreonine and dehydroserine).

Circular Dichroism (CD) Spectrum - CD spectra were measured with a JASCO J-40 spectropolarimeter at $25^{\circ} \mathrm{C}$. The light path of the cell used was 0.5 or $0.05 \mathrm{~cm}$. All data are expressed as molar ellipticity. Protein concentration was $10 \mu \mathrm{M}$.

\section{Results}

\section{SDS Slab Electrophoresis of RNase Rh Preparation Having Low Specific Activity}

The Specific activity of RNase Rh purified according to the previous paper ${ }^{2)}$ is about $237 \mathrm{unit} / \mathrm{mg}$. However, we often observed RNase Rh preparations having low specific activity, such as $170-200 \mathrm{unit} / \mathrm{mg}$. On disc electrophoresis at $\mathrm{pH} 8.5$, such a preparation gave a single protein band at essentially the same location as RNase Rh having high specific activity. However, on $7 \%$ SDS disc electrophoresis in the presence of 2-mercaptoethanol, the low specific activity preparation gave two major bands and a very faint band having higher mobility (not seen in Fig. 1); one of the major bands had the same mobility as the high specific activity band and the other band showed slightly higher mobility. In order to estimate the molecular weight of the protein species involved in low specific activity preparation, it was subjected to $12 \%$ SDS slab electrophoresis in the presence of 2-mercaptoethanol. Two additional bands were seen, as well as a protein band having the same mobility as RNase Rh.

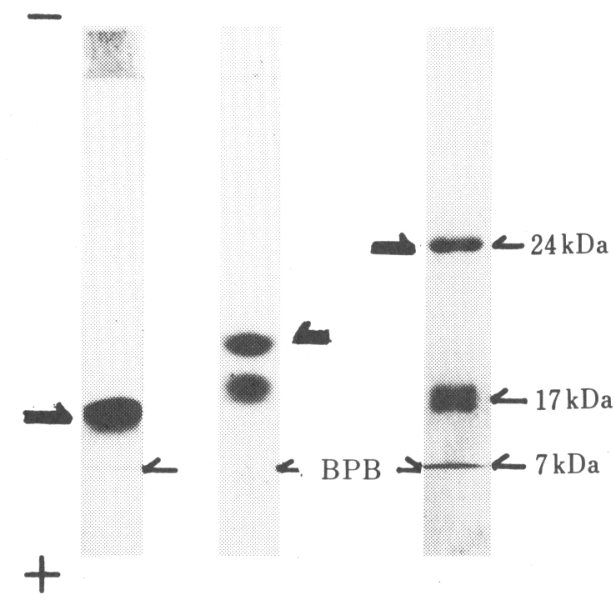

Fig. 1. Gel Electrophoreses of an RNase Rh Preparation Having Low Specific Activity (216 unit $/ \mathrm{mg}$ )

Left column, disc electrophoresis at $\mathrm{pH} 8.5$, in the absence of 2-mercaptoethanol; middle column, $7 \%$ SDS disc electrophoresis; right column, $12 \%$ SDS slab electrophoresis. Heavy arrows indicate the mobility of the native RNase Rh. The electrophoreses were performed as described in Materials and Methods. 
The molecular weights estimated by electrophoresis of these three bands were 24,17 and 7 kilodalton $(\mathrm{kDa})$. Since $24 \mathrm{kDa}$ is the molecular weight of the native RNase $\mathrm{Rh}$, the other two bands might be due to the low specific activity species. The sum of these two bands coincides with that of native RNase $\mathrm{Rh}(24 \mathrm{kDa})$, and the presence of these two extra bands indicated the cleavage of $\mathrm{RNase} \mathrm{Rh}$, probably by proteases. The fact that we were not able to observe these two bands, 17 and $7 \mathrm{kDa}$ in the absence of 2-mercaptoethanol indicated that the enzyme preparation having low specific activity consists of the 7 and $17 \mathrm{kDa}$ species connected by S-S bridges. Hereafter, we designate this modified enzyme preparation as RNase Rh'.

\section{Fractionation of Low Specific Activity RNase $R^{\prime}$ ' by DEAE-Toyopearl Column Chromatography}

The elution patterns on DEAE-Toyopearl 650M column chromatography of two enzyme preparations having specific activity 216 and $172 \mathrm{unit} / \mathrm{mg}$ are shown in Fig. 2a and 2b. In the former preparation, two RNase peaks appeared in addition to the major RNase peak corresponding to $\mathrm{RNase} \mathrm{Rh}$. In the latter preparation we observed a very small $\mathrm{RNase} \mathrm{Rh}$ peak and two other enzyme peaks. SDS-slab electrophoresis of these two enzymes in the presence of 2-mercaptoethanol indicated the presence of the $17 \mathrm{kDa}$ protein band and, thus they were RNase $\mathrm{Rh}^{\prime}$. By this step of purification, we could separate RNase Rh and RNase $\mathrm{Rh}^{\prime}$ species very effectively. In this work, we tried to characterize the major $\mathrm{RNase} \mathrm{Rh}^{\prime}$

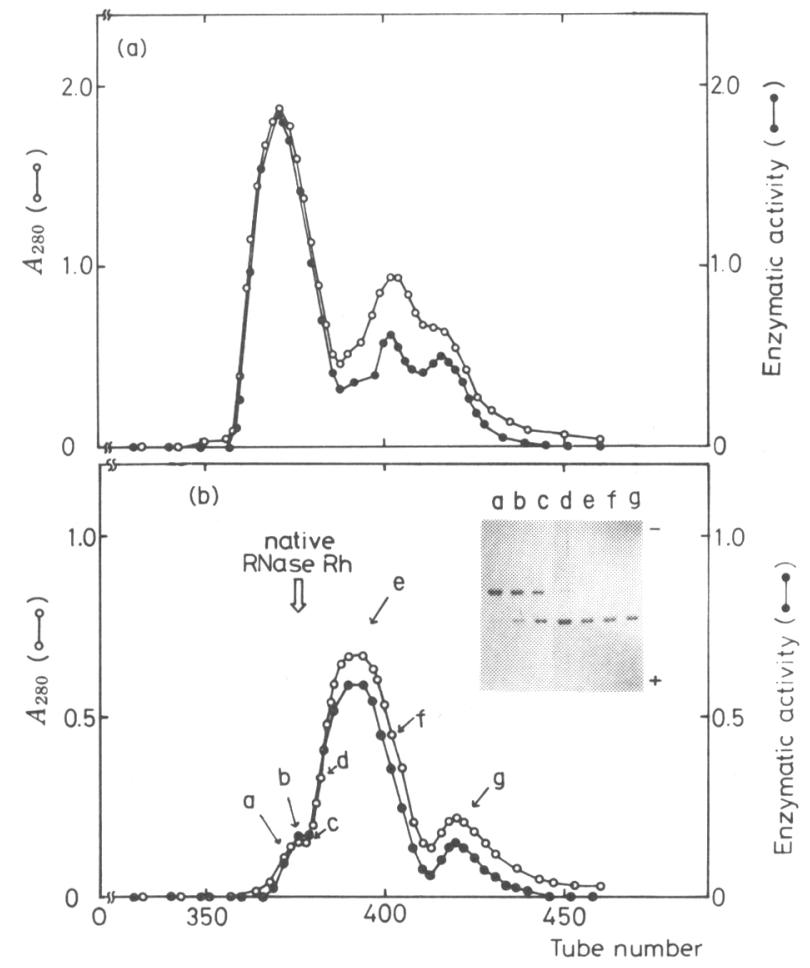

Fig. 2. DEAE-Toyopearl 650M Column Chromatography

(a) The enzyme preparation (specific activity $216 \mathrm{unit} / \mathrm{mg}$ ) was applied to a column of DEAE-Toyopearl $650 \mathrm{M}(1.8 \times 80 \mathrm{~cm})$ equilibrated with $50 \mathrm{mM}$ Tris- $\mathrm{HCl}$ buffer $(\mathrm{pH} 7.5)$. The enzyme was eluted with a linear gradient of $\mathrm{NaCl}$ from $0-0.2 \mathrm{M}$ in the same buffer. Each $5.0 \mathrm{ml}$ fraction was collected. $\bigcirc, A_{280}$ (protein);,$A_{260}$ (activity). The other experimental conditions were the same as described in Materials and Methods.

(b) The enzyme preparation (specific activity $172 \mathrm{unit} / \mathrm{mg}$ ) was applied to the same column as in Fig. 2a. The other experimental conditions were the same as in Fig. 2a. The inset shows the results of slab electrophoresis of the fractions indicated by $\mathrm{a}-\mathrm{g}$. 


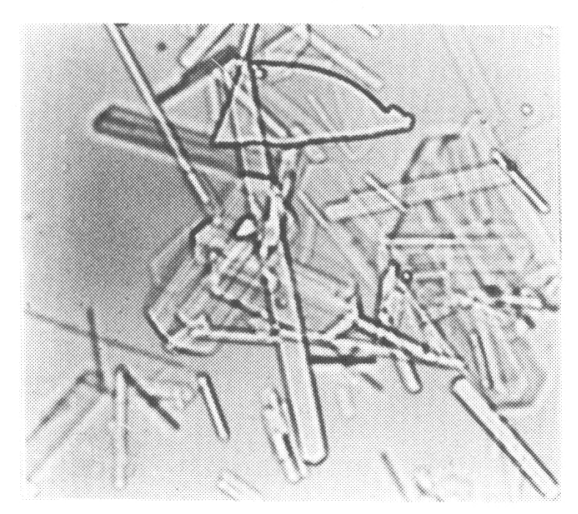

Fig. 3. Crystals of RNase $\mathrm{Rh}^{\prime}$
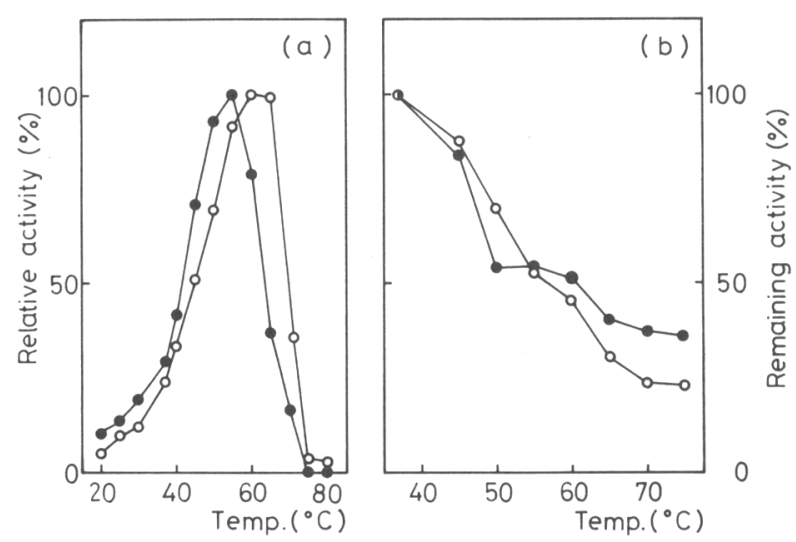

Fig. 4. Effect of Temperature on the Activities of RNase Rh and RNase Rh

(a) Effect of temperature on the activities of RNase Rh and RNase $\mathrm{Rh}^{\prime}$. The enzymatic activities of RNase Rh and RNase Rh' (specific activity 172 unit/mg) were measured at the temperature indicated by use of the standard assay system except for the temperature. The ordinate shows percent of the maximum activity.

(b) Stability of RNase Rh and RNase Rh' to heating. The enzyme (60 $\mu \mathrm{g})$ in acetate buffer ( $\mathrm{pH}$ 5.0) was incubated at the indicated temperature for $5 \mathrm{~min}$, then the enzymatic activity was measured at $37^{\circ} \mathrm{C}$. O, RNase $\mathrm{Rh} ; \bullet$, RNase $\mathrm{Rh}^{\prime}$.

component which was eluted just after RNase Rh (specific activity, 160 unit/mg).

\section{Crystallization of $\mathbf{R N a s e} \mathbf{R h}^{\prime}$}

$\mathrm{RNase} \mathrm{Rh}^{\prime}$ thus obtained was concentrated to a small volume (several $\mathrm{mg} / \mathrm{ml}$ ), then dialyzed against deionized water. The crystalline materials formed after exhaustive dialysis were collected by centrifugation. The photograph of typical crystals is shown in Fig. 3.

\section{Effect of Temperature on the Enzymatic Activity and Heat Stability of RNase Rh'}

The effect of temperature on the enzymatic activity of RNase Rh' was studied at pH 5.0 and compared with that of RNase Rh. Although the optimum temperature of RNase $\mathrm{Rh}^{\prime}$ was about $10^{\circ} \mathrm{C}$ less than that of RNase $\mathrm{Rh}$, the heat stabilities of the enzymes were comparable (Fig. 4).

\section{Spectrum of RNase $\mathbf{R h}^{\prime}$}

The CD spectra of RNase $\mathrm{Rh}^{\prime}$ and RNase Rh measured at $\mathrm{pH} 5.0$ and room temperature were almost superimposable, indicating similarity in the gross conformation of both enzymes.

\section{Amino Acid Sequences of 17 and 7 kDa Proteins}

In order to estimate the locations of the 17 and $7 \mathrm{kDa}$ proteins in $\mathrm{RNase} \mathrm{Rh}$, the two 


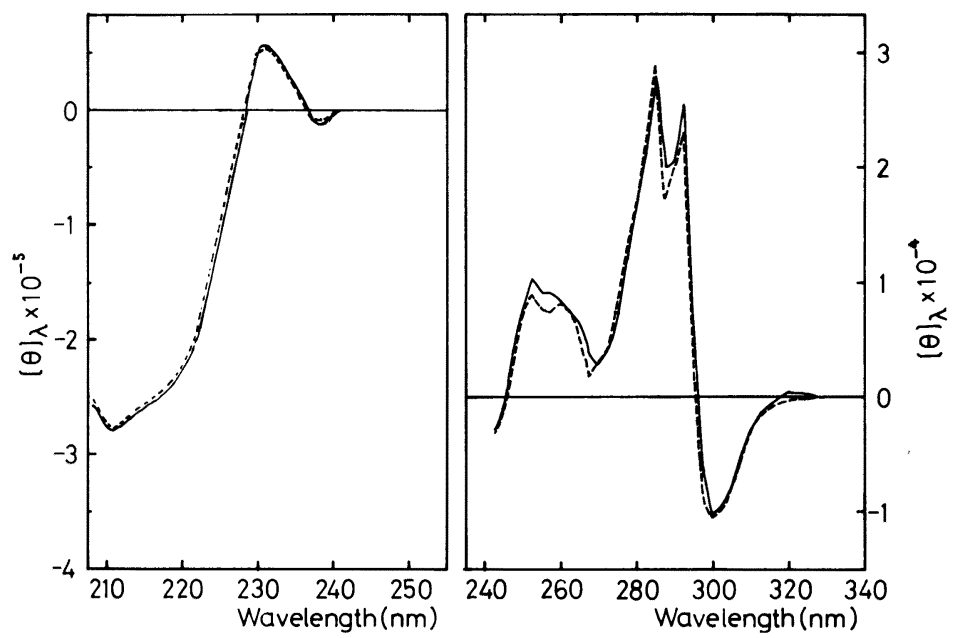

Fig. 5. CD Spectra of RNase $R h$ and $R$ Nase $R h^{\prime}$

- $\mathrm{RNase} \mathrm{Rh}$; ----, RNase $\mathrm{Rh}^{\prime}$. The experimental conditions were the same as described in Materials and Methods.

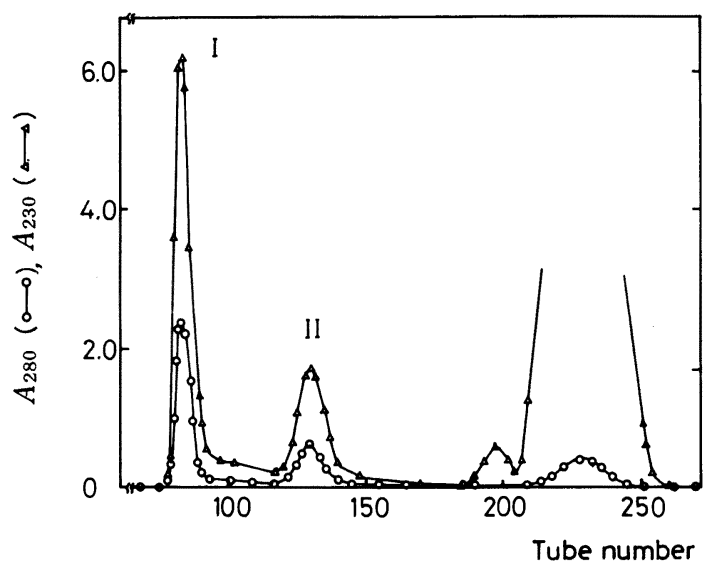

Fig. 6. Sephadex G-50 Column Chromatography of RCM RNase Rh'

$\mathrm{RCM}$ RNase $\mathrm{Rh}^{\prime}(1.5 \mu \mathrm{mol})$ was applied on a Sephadex G-50 column $(1.8 \times 210 \mathrm{~cm})$ equilibrated with $50 \mathrm{~mm}$ trimethylamine-acetate buffer $(\mathrm{pH} 8.0)$. Each $2.0 \mathrm{ml}$ fraction was collected. The column was eluted with the same buffer. $O, A_{280} ; \triangle, A_{230}$.

peptides were fractionated after reduced carboxymethylation of $\mathrm{RNase} \mathrm{Rh}^{\prime}$ by gel-filtration on a Sephadex G-50 column (Fig. 6). The high and low molecular weight components, component I and II, respectively, were pooled separately. The molecular weights of both components were estimated by gel filtration on Sephadex G-50 to be 17000 and $6-7000$. The amino acid compositions of both components are shown in Table I. The sum of both components is very similar to the composition of the RNase $\mathrm{Rh}$. The amino-terminal sequences of RCM RNase Rh, components I and II were determined by Edman degradation. The results are shown in Fig. 7. Since the N-terminal amino acid sequence of component II was the same as that of RNase $\mathrm{Rh}$, it was concluded that component II corresponds to the $\mathrm{NH}_{2}$-terminal 50 residues or so of $\mathrm{RNase} \mathrm{Rh}$, and component $\mathrm{I}$ is the $\mathrm{C}$-terminal $160-170$ residues of $R$ Nase $R h$. It was concluded that $R$ Nase $R h^{\prime}$ consists of the enzyme species cleaved at about 50 amino acid residues from the $\mathrm{N}$-terminal. However, the two peptides are connected by $\mathrm{S}-\mathrm{S}$ bridges so that the enzyme retained $c a .70 \%$ of the activity of the native RNase Rh. 


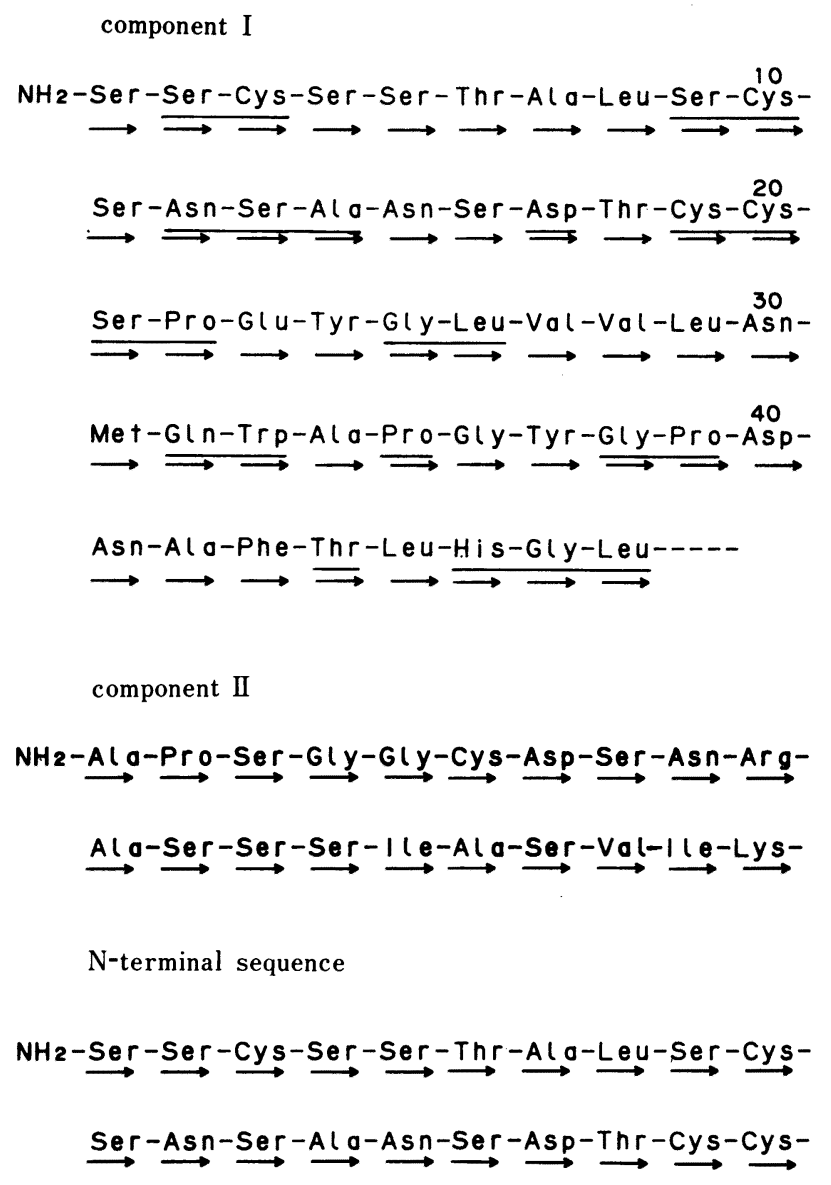

Fig. 7. N-Terminal Amino Acid Sequences of RNase Rh and Components I and II Derived from RNase $\mathrm{Rh}^{\prime}$

$\rightarrow$ indicates each step of Edman degradation.

\section{Discussion}

RNase $\mathrm{Rh}^{\prime}$, which has about $70 \%$ of the activity of native $\mathrm{RNase} \mathrm{Rh}$, has a very similar conformation to RNase $\mathrm{Rh}$ as judged from $\mathrm{CD}$ spectrum, and could be crystallized easily in spite of its proteolytic modification. The contribution of protease(s) to the formation of RNase $\mathrm{Rh}^{\prime}$ is supported by the fact that when we prepared crude $\mathrm{RNase} R \mathrm{~h}$ at room temperature instead of in a cold room, the yield of $\mathrm{RNase} \mathrm{Rh}^{\prime}$ increased markedly.

The evidence described here also indicated that the amino acid residues around the 50th position probably form a loop located at the surface of the molecule, being very susceptible to proteases during purification. This part of the molecule is probably far from the active site of $\mathrm{RNase} \mathrm{Rh}$. Component II of the minor RNase $\mathrm{Rh}^{\prime}$ (the fraction between tube No. $420-450$ in Fig. 2) gave the N-terminal sequence Gly-Gly-Cys-Asp---. Thus the proteases also attack between $3 \mathrm{rd}$ and 4 th amino acid residues from the $\mathrm{N}$-terminal of component $\mathrm{I}$ as well.

These enzyme species are very useful for chemical modification studies of RNase Rh, because the site of a chemically modified group at the N-terminal part of the molecule could be easily determined after separation of this part. The application of this enzyme for chemical modification studies will be reported in a separate paper. 
Table I. Amino Acid Compositions of Components I and II Obtained from RNase $\mathrm{Rh}^{\prime}$

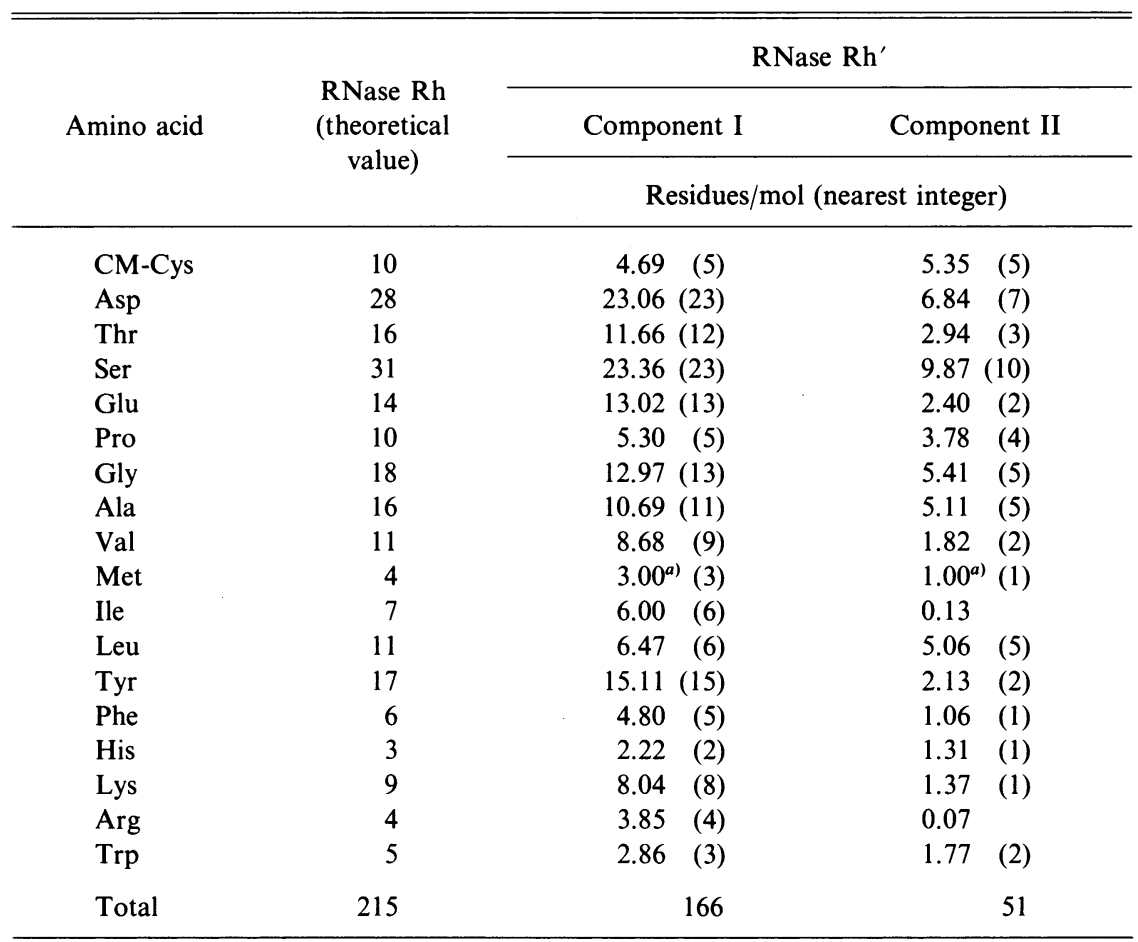

a) Assumed as Met 3.00 and 1.00 residues per mol for components I and II, respectively.

During the course of characterization, we determined the sequence of the $\mathrm{NH}_{2}$-terminal 48 amino acid residues of $\mathrm{RNase} \mathrm{Rh}$. When this sequence is compared with that of the similar base non-specific and adenylic acid preferential RNase, RNase $\mathrm{T}_{2}$ from Aspergillus oryzae, ${ }^{13}$ ) several homologous sequences can be seen. They are underlined in Fig. 7.

Acknowledgement The authors thank Amano Pharmaceutical Co., Ltd., for the kind gift of the enzyme source Gluczyme.

\section{References}

1) M. Tomoyeda, Y. Eto, and T. Yoshino, Arch. Biochem. Biophys., 131, 191 (1969).

2) T. Komiyama and M. Irie, J. Biochem., 70, 765 (1971).

3) D. M. MacFadyen, J. Biol. Chem., 107, 297 (1934).

4) L. Ornstein, Ann. N. Y. Acad. Sci., 121, 321 (1964).

5) B. J. Davis, Ann. N. Y. Acad. Sci., 121, 404 (1964).

6) A. L. Shapiro, E. Vinevela, and J. V. Maizel, Biochem. Biophys. Res. Commun., 28, 815 (1967).

7) U. K. Laemmli, Nature, 227, 680 (1970).

8) P. Andrews, Biochem. J., 91, 222 (1964).

9) D. H. Spackman, W. H. Stein, and S. Moore, Anal. Chem., 30, 1190 (1956).

10) P. Pajot, Eur. J. Biochem., 63, 263 (1976).

11) A. M. Crestfield, S. Moore, and W. H. Stein, J. Biol. Chem., 238, 622 (1963).

12) B. Blombäck, M. Blombäck, P. Edman, and B. Hessel, Biochim. Biophys. Acta, 115, 371 (1966).

13) Y. Kawada and F. Sakiyama, Abstracts of Papers, The 34th Symposium on Protein Structure, Sendai, September 1985, p. 17. 